\title{
RUNOFF CHARACTERISTICS IN FOREST PLOTS BEFORE AND AFTER WOOD ASH FERTILIZATION
}

\author{
Avelino Núñez-Delgado ${ }^{1}$, Francisco Quiroga-Lago ${ }^{1}$, Benedicto Soto-González ${ }^{2}$
}

\begin{abstract}
Spreading wood ash on forest and agricultural lands has been used for years to correct $\mathrm{pH}$ in acid soils and as a source of plant nutrients. However, it is necessary to enhance the knowledge of potential hazards derived from such a practise. Surface runoff pollution is one of these possible hazards. In this work we studied the quality of runoff water collected in two sloped forest plots before and after wood ash spreading, with the aim of checking potential undesirable effects of ash use. We have not found environmental pollution problems in runoff derived from the ash application zones. These results encourage further research and use of wood ash as an amendment in acid sloped forest soils.
\end{abstract}

Keywords: Wood ash, experimental plots, runoff, water quality

\section{INTRODUCTION}

Tree harvesting operations contribute to the impoverishment of the soil at the time that wood is removed. This circumstance is still more accused in acid soils, where low $\mathrm{pH}$ affects on the properties of soils and consequently on the plant nutrient uptake. Therefore, it would be of value having an unexpensive waste material that could correct the $\mathrm{pH}$ of acid soils and that at the same time would increase plant nutrient levels.

Felled trees are generally transported to the wood and paper mill transformation industries where the non-utilisable parts (bark, leaves, fruits) may be used as a source of energy by burning it in boilers conceived for this purpose, giving wood ash as a waste or by-product. Someshwar (1996) estimated a production of wood ash of about 1.5-3 million tons/year in the USA, originated from the combustion of wood and coal in forest industries. It is also estimated that more than $80 \%$ of this residue is land filled without another solution (Campbell 1990). In Sweden, the estimated wood ash generation is about 200.000 tons/year, also land filled in most of the occasions (Piirainen 2001). In Galicia (NW Spain), most wood factories include this activity in their productive process and the ash production is estimated in about 40.000 tons/year (Sueiro 2010).

Wood ash is a very heterogeneous material with characteristics depending on the species and the type of vegetable, burning parts (bark, timber, fruits), combination with other flammable materials, burning and storage conditions. However, wood ashes always show high alkalinity -with $\mathrm{pH}$ values above 10 in most of the cases - (Demeyer et al. 2001, Someshwar 1996), and high levels of $C a$ and $K$, and occasionally $M g$, in form of oxides, hydroxides and carbonates (Campbell 1990). Elements such as $C$ and $N$ can be present if combustion was not complete, or be volatilised otherwise (Someshwar 1996, Muse and Mitchell 1995). Si and Al may appear if sand is adhered to the wood during tree falling operations (Someshwar 1996). Microelement concentrations are very variable, Fe being the most

\footnotetext{
${ }^{1}$ Departamento Edafología y Química Agrícola, Universidad Santiago de Compostela. Escuela Politécnica Superior, Campus Univ. s/n, 27002 Lugo. Spain ${ }^{2}$ Departamento Biología Vegetal y Ciencias del Suelo, Universidad Vigo, Facultad de Ciencias, 32004 Ourense. Spain.

Corresponding author: avelino.nunez@usc.es

Received: 20.01. 2011 Accepted: 17.07. 2011
} 
abundant (Someshwar 1996, Ohno 1992, Ohno and Erich, 1990). According to Someshwar (1996) these ashes have low or very low $\mathrm{Se}, \mathrm{Hg}, \mathrm{Cd}$ and $\mathrm{Co}$ contents, and may have high $\mathrm{As}, \mathrm{Ni}, \mathrm{Cr}, \mathrm{Pb}, \mathrm{B}$ and $\mathrm{Mn}$ concentrations. Etiégni and Campbell (1991) affirm that $Z n$ content is reduced when falling burning temperature, while other metallic ion concentrations can be maintained or be increased. According to Someshwar (1996) wood ashes may contain polycyclic aromatic hydrocarbons (PAH), chlorobenzenes or chlorophenols, but with concentrations generally considered not hazardous.

Some of the described wood ash characteristics are interesting as regards soil fertility (such as high alkalinity or macro and micronutrients contents). For this reason, spreading of wood ash on agricultural and forest soils as well as in cut-away peatlands with high acidity and/or low fertility has been previously studied. Several experiences were made with satisfactory results (for example: Erich 1991, Etiégni et al. 1991, Huang et al. 1992, Huotari et al. 2011). Some studies show a faster reaction of ashes than that of lime in the soil (Clapham and Zibilske 1992, Muse and Mitchell 1995), with higher initial pH increase in ash amended soils, although maintained in a shorter period of time. Wood ash spreading on forest soils can increase long-term production (Vance 1996, Moilanen et al. 2002). Pine and willow growth on organic soils in Finland increased notably after wood ash spreading compared to non-treated soil (Silfverberg and Hotanen 1989).

However, it is necessary to assess the pollution potential of wood ash, in runoff flowing towards water courses nearby the application areas. Different legal regulations related to this aspect would be considered before utilisation of wood ashes. The use of lime complexes are regulated by legislation in countries like Germany, while others regulate the using of biosolids (USEPA 1993). Regarding to the effects that these ashes may cause on runoff water, it would be necessary to take into account different state rules or guide values referring to water quality (WHO, 1998). Utilisation of wood ashes in protected areas would preferably be avoided.

Campbell (1990) indicates that contents of harmful elements in wood ashes are generally low, and specifically these ashes would have low concentrations of heavy metals (Naylor and Schmidt 1986, Campbell 1990, Etiegni et al. 1991, Muse and Mitchell 1995). An application rate of $10 \mathrm{Mg} \mathrm{ha}^{-1}$ could be safe as regards the USEPA recommended limits for sewage sludge. Campbell (1990) suggests that $\mathrm{pH}$ changes and $\mathrm{K}$ concentrations due to ash addition could be more astringent than heavy metals contents. However, ashes originating from painted or impregnated wood must be avoided (Zollner and Remler 1998). A study of Büttner et al. (1995) concludes that, during a short period, a water pollution risk may exist at the zone amended at relatively high doses $\left(18 \mathrm{Mg} \mathrm{ha}^{-1}\right)$. However Williams et al. (1996) studying forest soils in the eastern coast of USA conclude that doses up to $44 \mathrm{Mg} \mathrm{ha}^{-1}$ did not increase concentrations of hazardous elements in infiltrated water, while low concentrations of heavy metals were retained in the soil. In another study, Moilanen et al. (2006) concluded that the heavy metals brought into the ecosystem by ash application are unlikely to be accumulated in any considerable amounts in forest berries and mushrooms.

Another aspect to take into account is the loss of nutrients due to rainfall and consequent leaching. Strong rainfall and high permeability of the soil, as well as low cationic exchange capacity, may lead to a rapid disappearance of the fertilising effects (Voundi et al. 2000). As per these authors, losses by percolation of $\mathrm{Ca}, \mathrm{Mg}, \mathrm{K}, \mathrm{NO}_{3}^{-}, \mathrm{SO}_{4}^{2-}$ and organic carbon were greater after ash spreading than after lime application, due to the greater solubility of $\mathrm{Ca}, \mathrm{Mg}, \mathrm{K}$ and salts in the soil-applied ashes, while micronutrients losses were not appreciable (Ohno 1992, Erich and Ohno 1992, Ulery et al. 1993).

The aim of the present study was to assess the risk of runoff pollution due to wood ash spreading on sloped forest experimental plots. A $10 \mathrm{Mg} \mathrm{ha}^{-1}$ dose of wood ash was applied. Runoff water samples were collected after storm episodes, both before and after ash spreading, and its physico-chemical parameters were analysed. 


\section{The site}

\section{MATERIAL AND METHODS}

The experimental plot was located in Sobrado (Baralla, Lugo, NW Spain). It was a plantation of Pseudotsuga menziensii two years old sited in a gently sloping area. Trees were planted in deep row furrows made in the soil. Planting frame was $3 \times 4 \mathrm{~m}\left(833\right.$ tree ha $\left.^{-1}\right)$.

Prior to the start of the studies on runoff, eight unstructured and eight core soil samples were taken randomly at 0-20 cm depth. The unstructured soil samples were subsequently dried, sieved and homogenised for being analysed, and the core samples were used to determine bulk density(as per Guitián and Carballas 1976; Page et al. 1982, Klute 1986, Tan 1996). Soil characteristics are showed in table 1.

Table 1. Physico-chemical characteristics of the soil

\begin{tabular}{|l|c|}
\hline$\%$ Sand & 53.15 \\
\hline$\%$ Silt & 32.66 \\
\hline$\%$ Clay & 14.19 \\
\hline Texture & Sandy-loam \\
\hline Particle density $\left(\mathrm{kg} \mathrm{m}^{-3}\right)$ & 1060 \\
\hline Bulk density $\left(\mathrm{kg} \mathrm{m}^{-3}\right)$ & 2350 \\
\hline $\mathrm{pH}_{\text {water }}$ & 4.48 \\
\hline $\mathrm{pH}_{\mathrm{KCl}}$ & 3.42 \\
\hline $\mathrm{EC}\left(\mu \mathrm{cm}^{-1}\right)$ & 74.55 \\
\hline $\mathrm{C}(\%)$ & 4.69 \\
\hline$\%$ Organic matter & 8.08 \\
\hline $\mathrm{TKN}(\%)$ & 0.18 \\
\hline $\mathrm{C} / \mathrm{N}$ & 26.06 \\
\hline $\mathrm{o}-\mathrm{P}\left(\mathrm{mg} \mathrm{P} \mathrm{Kg}^{-1}\right)$ & 0.36 \\
\hline $\mathrm{Na}\left(\mathrm{cmol}(+) \mathrm{Kg}^{-1}\right)$ & 1.96 \\
\hline $\mathrm{K}\left(\mathrm{cmol}(+) \mathrm{Kg}^{-1}\right)$ & 0.34 \\
\hline $\mathrm{Ca}\left(\mathrm{cmol}(+) \mathrm{Kg}^{-1}\right)$ & 1.0 \\
\hline $\mathrm{Mg}\left(\mathrm{cmol}(+) \mathrm{Kg}^{-1}\right)$ & 0.63 \\
\hline $\mathrm{Sum}\left(\mathrm{cmol}(+) \mathrm{Kg}^{-1}\right)$ & 3.93 \\
\hline $\mathrm{Al}\left(\mathrm{cmol}(+) \mathrm{Kg}^{-1}\right)$ & 2.13 \\
\hline $\mathrm{CECe}\left(\mathrm{cmol}(+) \mathrm{Kg}^{-1}\right)$ & 6.06 \\
\hline
\end{tabular}

$\mathrm{EC}=$ Electrical conductivity; TKN $=$ Total Kjeldahl Nitrogen; $\mathrm{C} / \mathrm{N}=$ Carbon/Nitrogen relationship; Sum $=$ Sum of exchangeable bases; $\mathrm{CECe}=$ Effective cation exchange capacity; Ortho-phosphate $(\mathrm{o}-\mathrm{P})$ was extracted using distilled water

A surface layer of decaying branches, needles and pine cones from a previous plantation of pines also exists on the hill, covering the whole site to a depth of about $10 \mathrm{~cm}$. Samples of these remains were taken, then extracted with water in a 1:20 solid: liquid relationship, shaking for 1 hour and filtering using Albet 145 filters, and then were analysed as per standard methods (Guitián and Carballas 1976, Page et al. 1982, Klute 1986, Tan 1996). Physico-chemical characteristics of the extracts from vegetable remains are showed in table 2. 
Table 2. Physico-chemical characteristics of the extracts from vegetable remains

\begin{tabular}{|c|c|}
\hline $\mathrm{pH}_{\text {water }}$ & 4.99 \\
\hline $\mathrm{E} \mathrm{C}\left(\mu \mathrm{S} \mathrm{cm}^{-1}\right)$ & 98.85 \\
\hline Ammonium $\left(\mathrm{mg} \mathrm{kg}^{-1}\right)$ & 212.1 \\
\hline Nitrate $\left(\mathrm{mg} \mathrm{kg}^{-1}\right)$ & 42.3 \\
\hline $\mathrm{COD}\left(\mathrm{mg} \mathrm{O}_{2} \mathrm{~g}^{-1}\right) ;$ & 6881.6 \\
\hline $\mathrm{O}-\mathrm{P}\left(\mathrm{mg} \mathrm{P} \mathrm{kg}^{-1}\right)$ & 27.2 \\
\hline $\mathrm{Na}\left(\mathrm{mg} \mathrm{kg}^{-1}\right)$ & 181.8 \\
\hline $\mathrm{K}\left(\mathrm{mg} \mathrm{kg}^{-1}\right)$ & 213.4 \\
\hline $\mathrm{Ca}\left(\mathrm{mg} \mathrm{kg}^{-1}\right)$ & 73.0 \\
\hline $\mathrm{Mg}\left(\mathrm{mg} \mathrm{kg}^{-1}\right)$ & 28.0 \\
\hline $\mathrm{Al}\left(\mathrm{mg} \mathrm{kg}^{-1}\right)$ & 14.6 \\
\hline
\end{tabular}

E C: Electrical conductivity; COD: Chemical Oxygen Demand; Ortho-phosphate (o-P) was extracted using distilled water

\section{The applied wood ash}

The amendment added on the plots, in a dose of $10 \mathrm{Mg} \mathrm{ha}^{-1}$, on February 15, was a mixture of $1: 1 \mathrm{fly}$ ash and coarse ash (volumetric relationship) collected at the timber factory of Tablicia S. A. (Lugo, NW Spain). Ash was spread uniformly across both plots and in all sub plots. The wood ash characteristics are showed in table 3.

This ash shows a high alkalinity index. Calcium levels are higher than that of all other basic cations. Heavy metals levels are low. These results are, in general, in accordance with those obtained by Demeyer et al.(2001).

Table 3. Physico-chemical characteristics of the applied wood ash

\begin{tabular}{|c|c|}
\hline Parameter & Value \\
\hline Moisture (\%) & 46.47 \\
\hline $\mathrm{pH}\left(\mathrm{H}_{2} \mathrm{O}\right)$ & 9.96 \\
\hline $\mathrm{pH}(\mathrm{KCl})$ & 9.70 \\
\hline $\mathrm{EC}\left(\mu \mathrm{S} \mathrm{cm}^{-1}\right)$ & 199.1 \\
\hline $\mathrm{O}-\mathrm{P}\left(\mathrm{mg} \mathrm{kg}^{-1}\right)$ & 28.15 \\
\hline $\mathrm{P}$ (Mehlich) $\left(\mathrm{mg} \mathrm{kg}^{-1}\right)$ & 967.5 \\
\hline $\mathrm{C}(\%)$ & 5.59 \\
\hline TK N (\%) & 0.16 \\
\hline $\mathrm{C} / \mathrm{N}$ & 34.94 \\
\hline $\mathrm{Ca}\left(\mathrm{mg} \mathrm{kg}^{-1}\right)^{*}$ & 24160 \\
\hline $\operatorname{Mg}\left(\mathrm{mg} \mathrm{kg}^{-1}\right)^{*}$ & 7710 \\
\hline $\mathrm{Na}\left(\mathrm{mg} \mathrm{kg}^{-1}\right) *$ & 1670 \\
\hline $\mathrm{K}\left(\mathrm{mg} \mathrm{kg}^{-1}\right)^{*}$ & 10855 \\
\hline $\mathrm{Cd}\left(\mathrm{mg} \mathrm{kg}^{-1}\right)^{*}$ & $<0.5$ \\
\hline $\mathrm{Cu}\left(\mathrm{mg} \mathrm{kg}^{-1}\right)^{*}$ & 6.11 \\
\hline $\mathrm{Hg}\left(\mathrm{mg} \mathrm{kg}^{-1}\right)^{*}$ & 0.02 \\
\hline $\mathrm{Pb}\left(\mathrm{mg} \mathrm{kg}^{-1}\right)^{*}$ & $<0.5$ \\
\hline $\mathrm{Ni}\left(\mathrm{mg} \mathrm{kg}^{-1}\right)^{*}$ & 21 \\
\hline $\mathrm{Cr}\left(\mathrm{mg} \mathrm{kg}^{-1}\right)^{*}$ & 28 \\
\hline $\mathrm{Zn}\left(\mathrm{mg} \mathrm{kg}^{-1}\right)^{*}$ & 72 \\
\hline
\end{tabular}

EC= Electrical conductivity; TKN= Total Kjeldahl Nitrogen; Ortho-phosphate (o-P) was extracted using water; * Total contains 
Two plots were used, labelled as "plot A" and "plot B". Both plots were $25 \mathrm{~m}$ long -on the direction of the slope - and $6 \mathrm{~m}$ wide. With the aim of investigating the influence on runoff characteristics of the existing row furrows and plains, each plot was divided in 5 sub-zones: 2 deep row furrows -where trees were planted - and 3 plain zones, one of them -the central one - being wider (see Figure 1). Galvanised iron plates were installed all along the limits of the plots. At the bottom limit of each plot a runoff collecting system, expressly designed for this study, was installed. A runoff storing device was also installed. A more detailed description of the system can be seen in Quiroga et al. (2002).

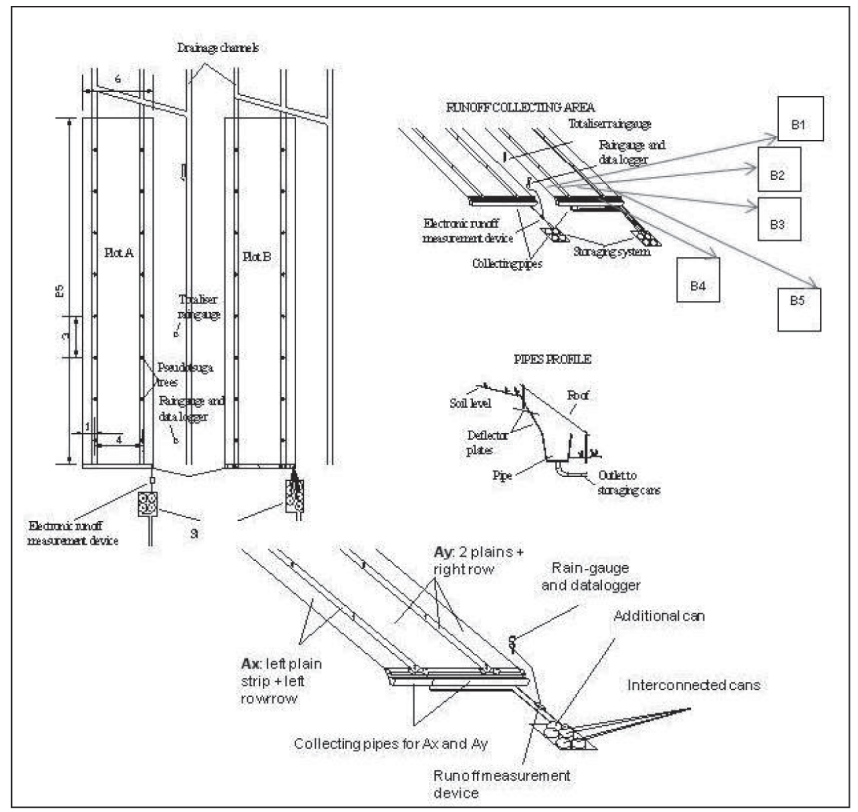

Figure 1. Plot layout and runoff collecting system. Distances in $\mathrm{m}$

\section{Runoff sampling was as follows:}

At the beginning of the study, all the runoff water of the whole plot A was collected in only one sample; later, on February 15, just before ash spreading, and in order to avoid overflowing in the storing cans, plot A was divided in 2 sampling zones (Ax and Ay). Ax sampling zone included the left lateral plain strip as well as the left row furrow, while Ay sampling zone comprised the remain of plot A. Sampling in plot $\mathrm{B}$ was divided in 5 different zones, corresponding to the left lateral plain strip (B1), the left row furrow (B2), the central plain strip (B3), the right row furrow (B4) and the right lateral plain strip (B5).

Four runoff events were sampled during two months before wood ash spreading, providing results on runoff water characteristics that could be seen as a previous control. After ash spreading, seven runoff events were sampled during four months. The amount of rainfall was also measured. Rainfall amount was clearly higher than monthly long term average in January $(247 v s .128 \mathrm{~mm})$ and March (398 vs. $193 \mathrm{~mm})$, while it was between 5 and $10 \%$ lesser than the long term average during the remainder months.

\section{Water sampling and analysis}

Water samples stored at the storage tanks were taken in polyethylene bottles, when runoff events took place. One runoff sample for the whole plot $A$ and five subsamples for plot $B$ (one for each subplot: B1, B2, B3, B4 and B5) were taken in each event prior to the division of the sampling of plot A in two parts. After that division, two samples for plot A (Ax and Ay) and five for plot B (B1 to B5) were taken. Storage tanks in plot B were weighed at the field using a digital scale in order to determine runoff volumes. Tanks were emptied and cleaned after each sampling. 
Runoff samples were analysed for $\mathrm{pH}$, electrical conductivity (EC), chemical oxygen demand (COD), $\mathrm{Ca}, \mathrm{Mg}, \mathrm{Na}, \mathrm{K}, \mathrm{Fe}, \mathrm{Zn}$ and $\mathrm{Ni}$ (as per APHA, 1998).

Tables 4 and 5 show rainfall and runoff amounts $(\mathrm{mm})$ for each runoff event in both plots.

Table 4. Rainfall and runoff in plot A

\begin{tabular}{|c|c|c|c|c|}
\hline $\begin{array}{c}\text { Runoff } \\
\text { event }\end{array}$ & $\begin{array}{c}\text { Runoff in } \\
\text { whole plot } \\
\text { A (mm) }\end{array}$ & $\begin{array}{c}\text { Runoff in } \\
\text { subplot } \\
\text { Ax (mm) }\end{array}$ & $\begin{array}{c}\text { Runoff in } \\
\text { subplot } \\
\text { Ay (mm) }\end{array}$ & $\begin{array}{c}\text { Rainfall } \\
(\mathrm{mm})\end{array}$ \\
\hline 1 & 21 & & & 118 \\
\hline 2 & 19 & & & 90 \\
\hline 3 & 25 & & 33 & 96 \\
\hline 4 & & 1 & 3 & 68 \\
\hline 5 & & 1 & 6 & 23 \\
\hline 6 & & 1 & 13 & 28 \\
\hline 7 & & 1 & 8 & 20 \\
\hline 8 & & 5 & 0.5 & 161 \\
\hline 9 & & 4 & 0.5 & 119 \\
\hline 10 & & 1 & 0.5 & 87 \\
\hline 11 & & & & \\
\hline & & & & \\
\hline
\end{tabular}

Table 5 Rainfall and runoff in plot B

\begin{tabular}{|c|c|c|c|c|c|c|}
\hline Runoff & $\begin{array}{c}\text { Runoff in } \\
\text { subplot } \\
\text { B1 }\end{array}$ & $\begin{array}{c}\text { Runoff in } \\
\text { subplot } \\
\text { B2 }\end{array}$ & $\begin{array}{c}\text { Runoff in } \\
\text { subplot } \\
\text { B3 }\end{array}$ & $\begin{array}{c}\text { Runoff in } \\
\text { subplot } \\
\text { B4 }\end{array}$ & $\begin{array}{c}\text { Runoff in } \\
\text { subplot } \\
\text { B5 }\end{array}$ & $\begin{array}{c}\text { Rainfall } \\
(\mathrm{mm})\end{array}$ \\
\cline { 1 - 5 } event & $(\mathrm{mm})$ & $(\mathrm{mm})$ & $(\mathrm{mm})$ & $(\mathrm{mm})$ & $(\mathrm{mm})$ & \\
\hline 1 & 0.5 & 14 & 0.5 & 3.5 & 0.5 & 118 \\
\hline 2 & 1.5 & 14 & 1 & 7 & 1 & 90 \\
\hline 3 & 0.5 & 9 & 0.5 & 7 & 1.5 & 96 \\
\hline 4 & 2 & 7 & 1 & 14 & 1.5 & 107 \\
\hline 5 & 0.5 & 0 & 0.5 & 0 & 0.5 & 68 \\
\hline 6 & 0.5 & 0 & 1 & 14 & 1.5 & 23 \\
\hline 7 & 2.5 & 14 & 1 & 14 & 1 & 28 \\
\hline 8 & 0 & 0 & 0.5 & 0 & 0.5 & 20 \\
\hline 9 & 0.5 & 11 & 0.5 & 0 & 0.5 & 161 \\
\hline 10 & 0.5 & 0.5 & 0.5 & 0 & 0.5 & 119 \\
\hline 11 & 0.5 & 0.5 & 0.5 & 0 & 0.5 & 87 \\
\hline
\end{tabular}




\section{RESULTS AND DISCUSSION}

\section{Physico-chemical parameters}

\section{pH value}

Figure 2 shows the time course evolution of this parameter in each of both plots. Substantial differences among runoff samples collected before and after ash spreading were observed in plot A. Before ash spreading, stable values between 4.41 and 5.07 were registered. At the first sampling date after ash spreading, an appreciable rise in $\mathrm{pH}$ was produced. This rise was of 1.36 and $1.52 \mathrm{pH}$ unities for Ax and Ay sub-zones respectively. Then, a gradual $\mathrm{pH}$ decrease was observed to 5.18 and 5.04 for sub-zones Ax and Ay respectively. A new rise was observed at the last two sampling dates, with values increasing about $0.6 \mathrm{pH}$ units.
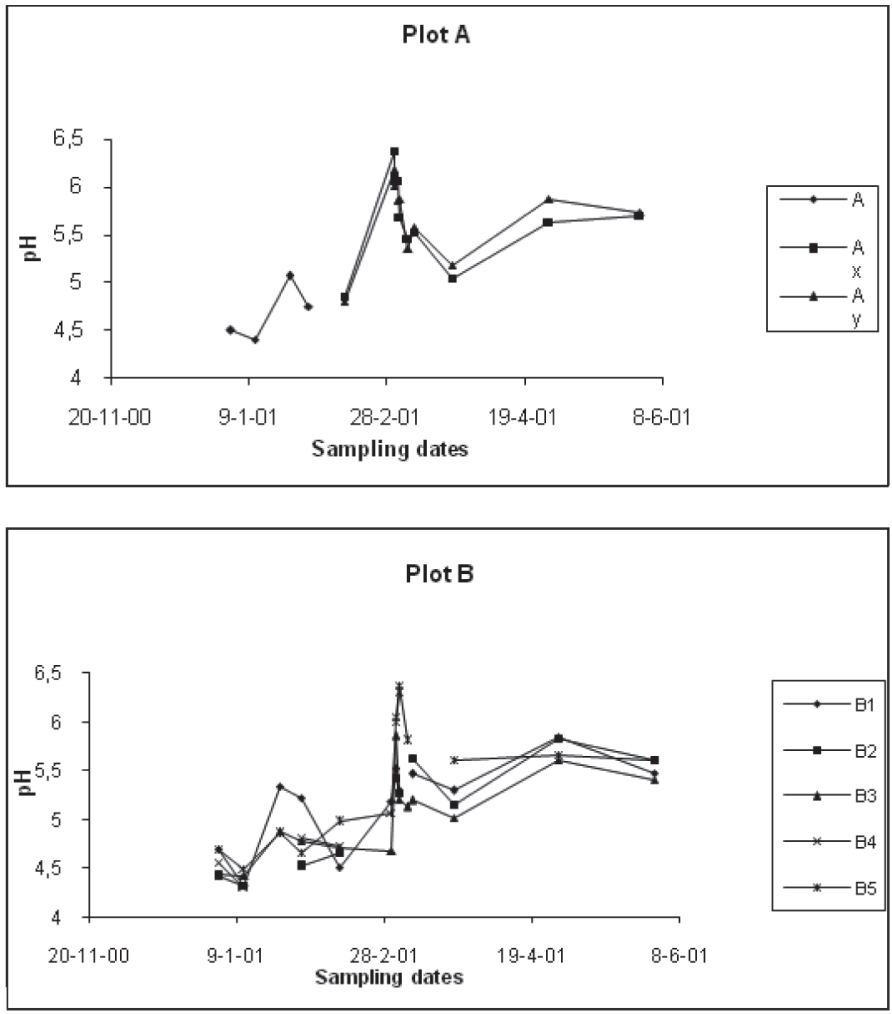

Figure 2: Time course evolution of $\mathrm{pH}$ in runoff samples collected in both plots. A: the whole plot A. Ax and Ay: sub-zones in plot A. B1 to B5: sub-zones in plot B

Similar dynamics were observed in plot B. A greater oscillation in $\mathrm{pH}$ values was produced prior to ash spreading (from 4.22 to 5.35). The rise after ash application was not so marked here, slightly perceived at the first sampling date after ash spreading (non-perceptible increases in sub-zones B3 and $\mathrm{B} 5$ and increases of 0.68 units in the sub-zone B1) and in a clear manner at the second sampling date in plot $B$ after ash spreading, with values between 0.78 and 1.17 units higher than those observed before wood ash amendment. A decrease was also observed until March 23, rising 0.6 units at the posterior sampling date, except in sub-zone B5 where $\mathrm{pH}$ was rather constant. At the last sampling date, a decrease of about $0.2-0.3$ units was produced in the zones affected by the previous $\mathrm{pH}$ rise. 
No significant correlations between runoff volumes and $\mathrm{pH}$ were found for both plots.

Possibly, the $\mathrm{pH}$ values in plot $\mathrm{B}$ took more time to increase due to the lesser runoff volumes generated in this plot, thus causing a delay in the arrival of basic cations to the runoff water collecting zone of the plot B. Another explanation could be that the lower runoff volumes generated in plot B are associated to greater infiltration ratios, with increased leaching of substances into the soil, even suffering retention in the exchange complex (Kahl et al. 1996).

\section{Electrical conductivity}

Results corresponding to this parameter appear in figure 3. Oscillating values between 20 and $30 \mu \mathrm{S}$ $\mathrm{cm}^{-1}$ were observed in plot A prior to the ash spreading. EC was between 25 and $40 \mu \mathrm{S} \mathrm{cm}^{-1}$ after ash addition, with the highest values at the two last sampling dates. This could be due to a progressive drag of soluble salts at different episodes, from the upper zones of the plot and all along it, to reach the runoff collecting zones, as previously described (Núñez et al. 2001).

Values between 10 and $40 \mu \mathrm{S} \mathrm{cm}^{-1}$ appear in the plot B just after the ash amendment, maintained until the last two sampling dates, and presenting a maximum of $54.7 \mu \mathrm{S} \mathrm{cm}^{-1}$ in this plot.

Similar tracing was observed for $\mathrm{EC}$ and $\mathrm{pH}$ (especially in the rises after ash spreading), due to some of the soluble salts affecting the degree of alkalinity of the runoff water.

As in the case of $\mathrm{pH}$, no significant correlation was found between runoff volume and $\mathrm{EC}$.
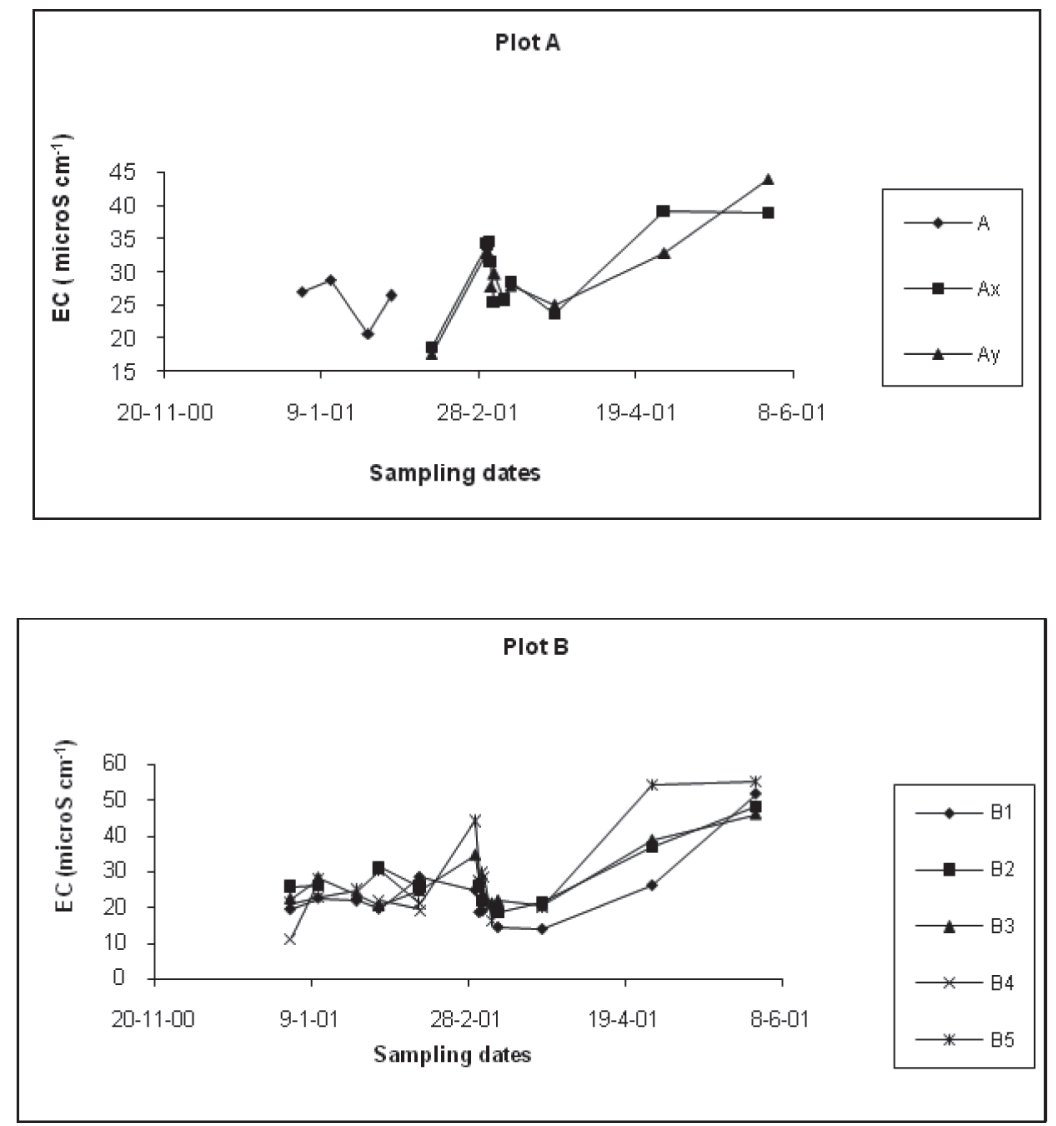

Figure 3. Time course evolution of the electrical conductivity $(\mu \mathrm{S} \mathrm{cm}-1)$ in runoff samples collected in both plots. A: the whole plot A. Ax and Ay: sub-zones in plot A.

B1 to B5: sub-zones in plot B 


\section{Chemical Oxygen Demand}

The values of COD appear in figure 4. Before ash spreading, COD values oscillated between 34.7 $\mathrm{mg} \mathrm{O}_{2} \mathrm{1}^{-1}$ and $116.6 \mathrm{mg} \mathrm{O}_{2} \mathrm{1}^{-1}$ in plot $\mathrm{A}$, and between $29.9 \mathrm{mg} \mathrm{O}_{2} \mathrm{1}^{-1}$ and $135.5 \mathrm{mg} \mathrm{O}_{2} \mathrm{1}^{-1}$ in plot $\mathrm{B}$. These values are highly dependent on the contribution of the vegetable remains over the soil, since the COD level of a water extract of these remains was of $6881 \mathrm{mg} \mathrm{O}_{2} 1^{-1}$ (Table 2).

Slightly higher COD values were observed at the first two sampling dates after wood ash spreading, with levels reaching up to $214.9 \mathrm{mg} \mathrm{O}_{2} \mathrm{l}^{-1}$, and always higher than $100 \mathrm{mg} \mathrm{O}_{2} \mathrm{l}^{-1}$ (except one sample for each plot). After this initial rise, presumably related to wood ash spreading, a variable behaviour was observed, with levels between 11 and $59.5 \mathrm{mg} \mathrm{O}_{2} \mathrm{l}^{-1}$ for plot A and between 14.4 and $112.8 \mathrm{mg} \mathrm{O}_{2} \mathrm{l}^{-1}$ for plot B. Increased COD values may be associated with solubilisation of organic matter due to the alkaline $\mathrm{pH}$ of the wood ash (Soto and Díaz-Fierros 1993).
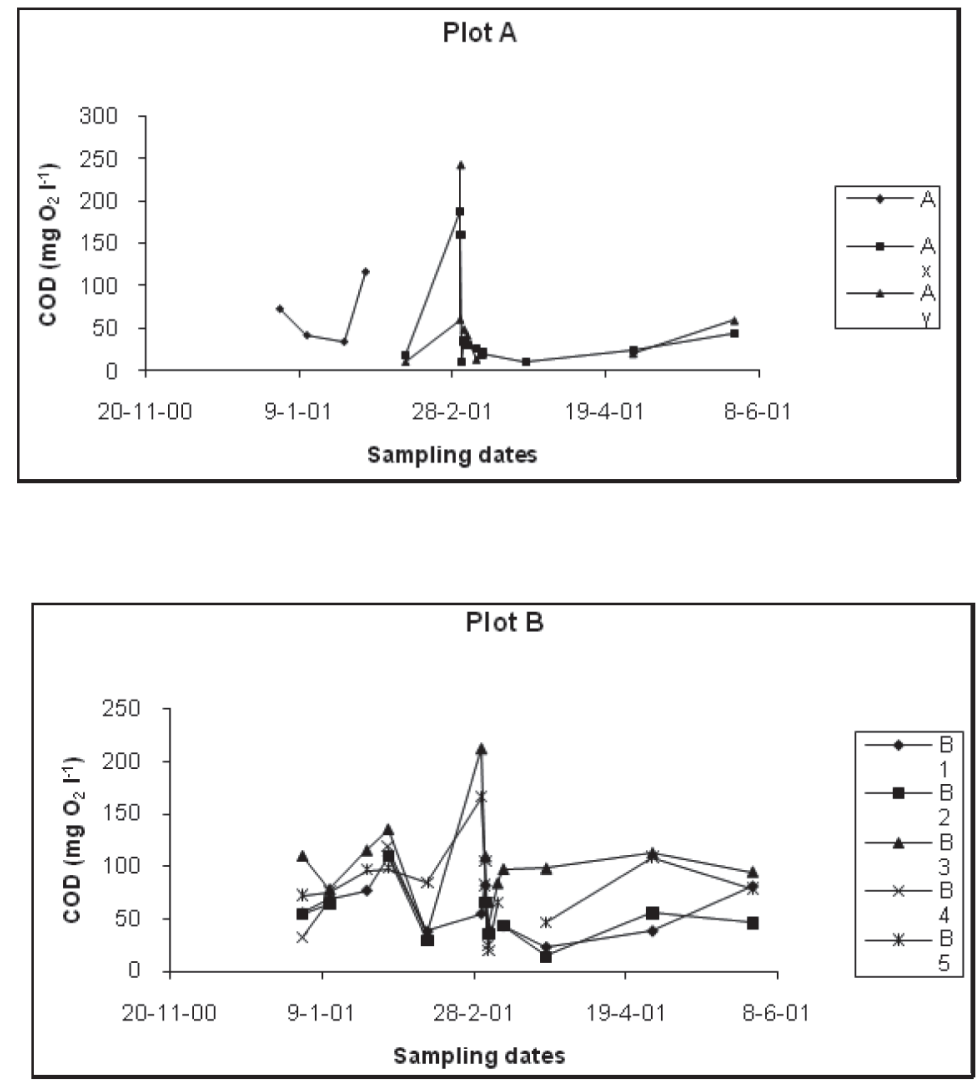

Figure 4. Time course evolution of the chemical oxygen demand (mg O2 1-1) in runoff samples collected in both plots. A: the whole plot A. Ax and Ay: sub-zones in plot A. B1 to B5: sub-zones in plot B

\section{Calcium}

Figure 5 shows that, before ash spreading, $\mathrm{Ca}$ concentrations were between 0.5 and $1 \mathrm{mg} \mathrm{l}^{-1}$ in runoff samples from plot A. Ca levels of 2.93 and $2.42 \mathrm{mg} \mathrm{l}^{-1}$ were found in the sub-zones Ax and Ay respectively just after ash spreading, with a subsequent decrease until March 4, when concentrations of 1.66 and 2.13 $\mathrm{mg}^{1^{-1}}$ were detected at the same sampling points. On March 7, peaks of 9.04 and $2.79 \mathrm{mg} \mathrm{Ca}{ }^{-1}$ were produced (with runoff volumes of 18.16 and more than 856.751 respectively, which do not situate the runoff volume as a determining factor in the appearance of these peaks), and immediately maintained at a rather constant level, between 1 and $1.5 \mathrm{mg} \mathrm{l}^{-1}$ until the end of the study. 

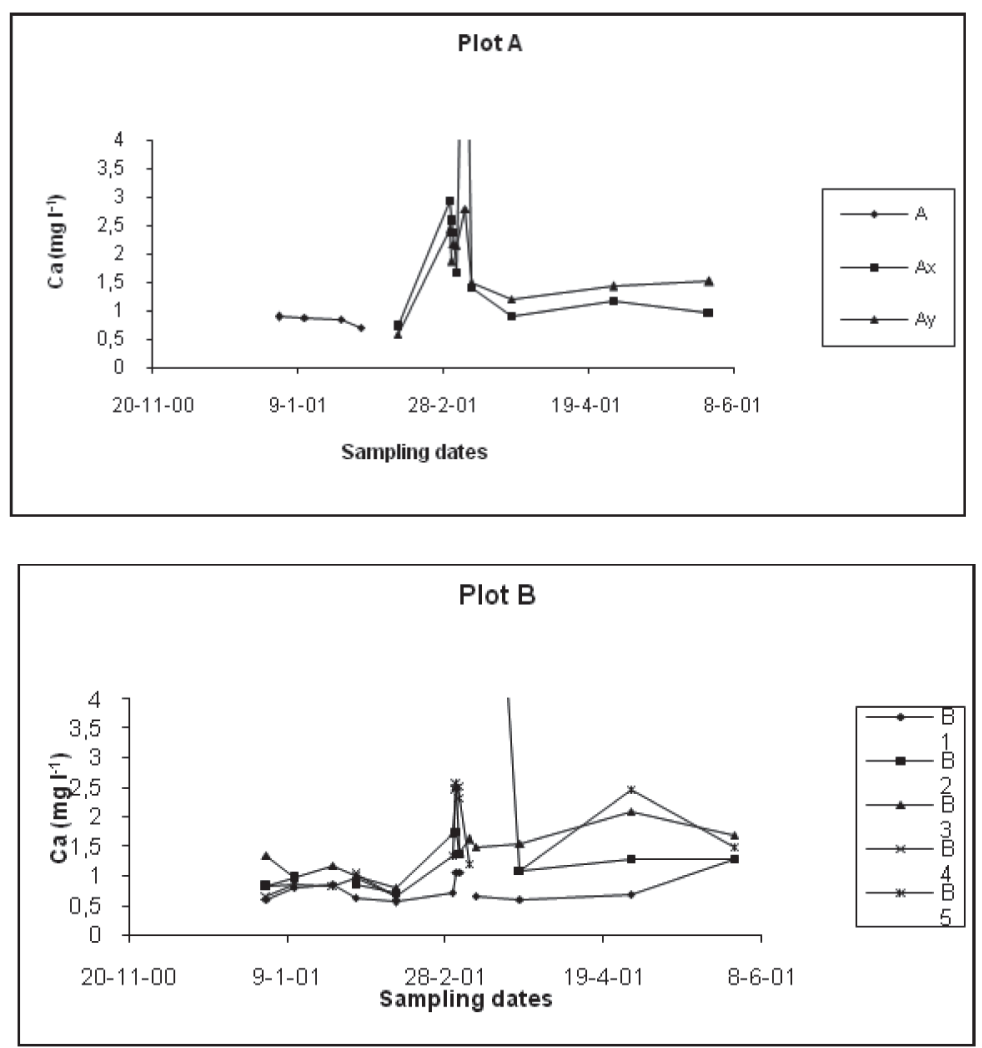

Figure 5. Time course evolution of $C a\left(\mathrm{mg} \mathrm{l}^{-1}\right)$ in runoff samples collected in both plots. A: the whole plot A. Ax and Ay: sub-zones in plot A. B1 to B5: sub-zones in plot B

In plot $\mathrm{B}, \mathrm{Ca}$ levels before ash spreading ranged from 0.6 to $1.34 \mathrm{mg} \mathrm{l}^{-1}$. In sub-zone $\mathrm{B} 1$ the increase of calcium levels at the first sampling date after ash spreading was scarcely noted (rise of $0.16 \mathrm{mg} \mathrm{l}^{-1}$ ). The next value was of $1.06 \mathrm{mg} \mathrm{l}^{-1}$ - and it was maintained for one more sampling date. $\mathrm{Ca}$ levels then decreased to about $0.4 \mathrm{mg} \mathrm{l}^{-1}$, presenting a final peak of $1.33 \mathrm{mg} \mathrm{l}^{-1}$. A final rise was more marked in the others sub-zones (increasing between 0.68 and $1.8 \mathrm{mg} \mathrm{Ca}^{-1}$ ), showing concentrations close to 2.5 $\mathrm{mg} \mathrm{l}^{-1}$. After that, values decreased to about 1-1.5 $\mathrm{mg} \mathrm{l}^{-1}$ in B2 (with a peak of $12.31 \mathrm{mg} \mathrm{l}^{-1}$ in March 9). Similar patterns were observed for B3 and B5. No clear evolution was observed in B4.

The reported increases in the levels of calcium are clearly attributable to the concentrations of this element present in the applied ash. Due to these increases, a repercussion in runoff $\mathrm{pH}$ values may be expected.

\section{Magnesium}

Figure 6 shows that, in plot A, $M g$ concentration in water runoff before the addition of the amendment was stabilised in values between 0.25 and $0.5 \mathrm{mg} \mathrm{l}^{-1}$.

After ash spreading the values rose to $0.7 \mathrm{mg}^{-1}$ and subsequently the concentration of $M g$ decreased gradually, with levels of 0.4 and $0.49 \mathrm{mg}^{-1}$ detected at the last sampling date in the sub-zones Ax and Ay respectively. 
In plot $\mathrm{B}, M g$ concentration before ash spreading was between 0.1 and $0.47 \mathrm{mg} \mathrm{l}^{-1}$. After the ash amendment, the variations in the content of this element in sub-zones B1 and B2 were scarcely appreciated, except at the last sampling dates. Increases of 0.3 and $0.5 \mathrm{mg} \mathrm{l}^{-1}$ respectively were observed in sub-zones B3 and B5 at the first sampling date after ash spreading, with a subsequent stabilisation in lower values until the last two sampling dates, when a new increase was observed. As well as in the case of calcium, similarities between the evolution of $M g$ and $\mathrm{pH}$ were verified, especially with reference to the increases of both values after the addition of ash. No significant correlation was found between runoff volumes and $M g$ concentrations.
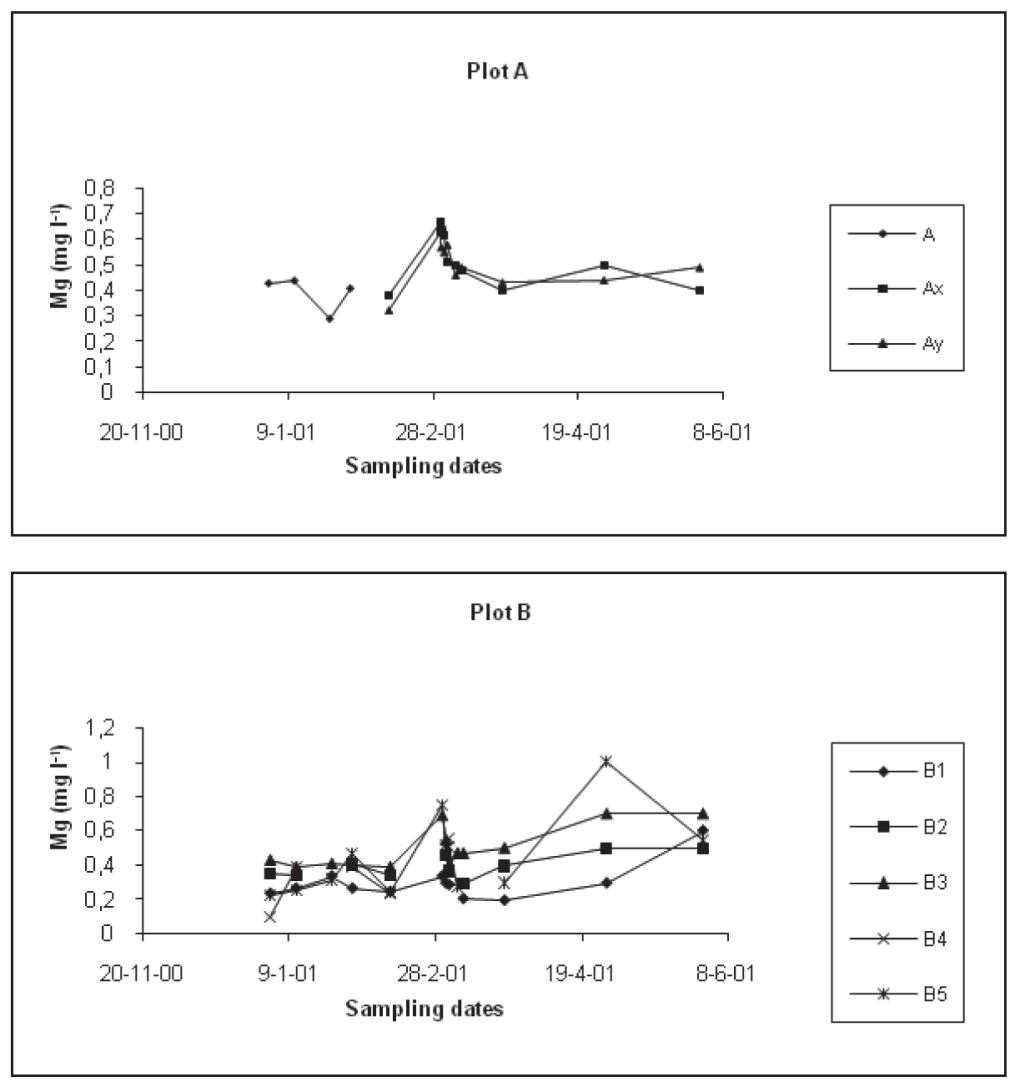

Figure 6. Time course evolution of $\mathrm{Mg}\left(\mathrm{mg} \mathrm{l}^{-1}\right)$ in runoff samples collected in both plots. A: the whole plot A. Ax and Ay: sub-zones in plot A. B1 to B5: sub-zones in plot B

\section{Sodium}

The concentrations of sodium in plot A were stable between 1-1.5 $\mathrm{mg} \mathrm{l}^{-1}$ before ash spreading (Figure 7). A rise of $0.4 \mathrm{mg} \mathrm{l}^{-1}$ in samples from the two sub-zones of the plot A was observed after ash spreading.

Plot B shows the following dynamics: the presence of sodium was between 1 and $1.5 \mathrm{mg} \mathrm{l}^{-1}$ before the ash treatment, appearing a peak immediately after ash spreading (with rises of between 0.27 and 1.37 $\mathrm{mg}^{1^{-1}}$ ) and finally values return to the initial levels. A new rise is produced after March 23, reaching the maximum sodium concentration on May 30 in sub-zone B2 (3.06 $\left.\mathrm{mg} \mathrm{l}^{-1}\right)$. The evolution of sodium is similar to that of the electrical conductivity (see also Figure 3), showing the importance of sodium salts on the EC values. As in previous cases, no significant correlations were found between runoff volumes and $\mathrm{Na}$ concentrations. 

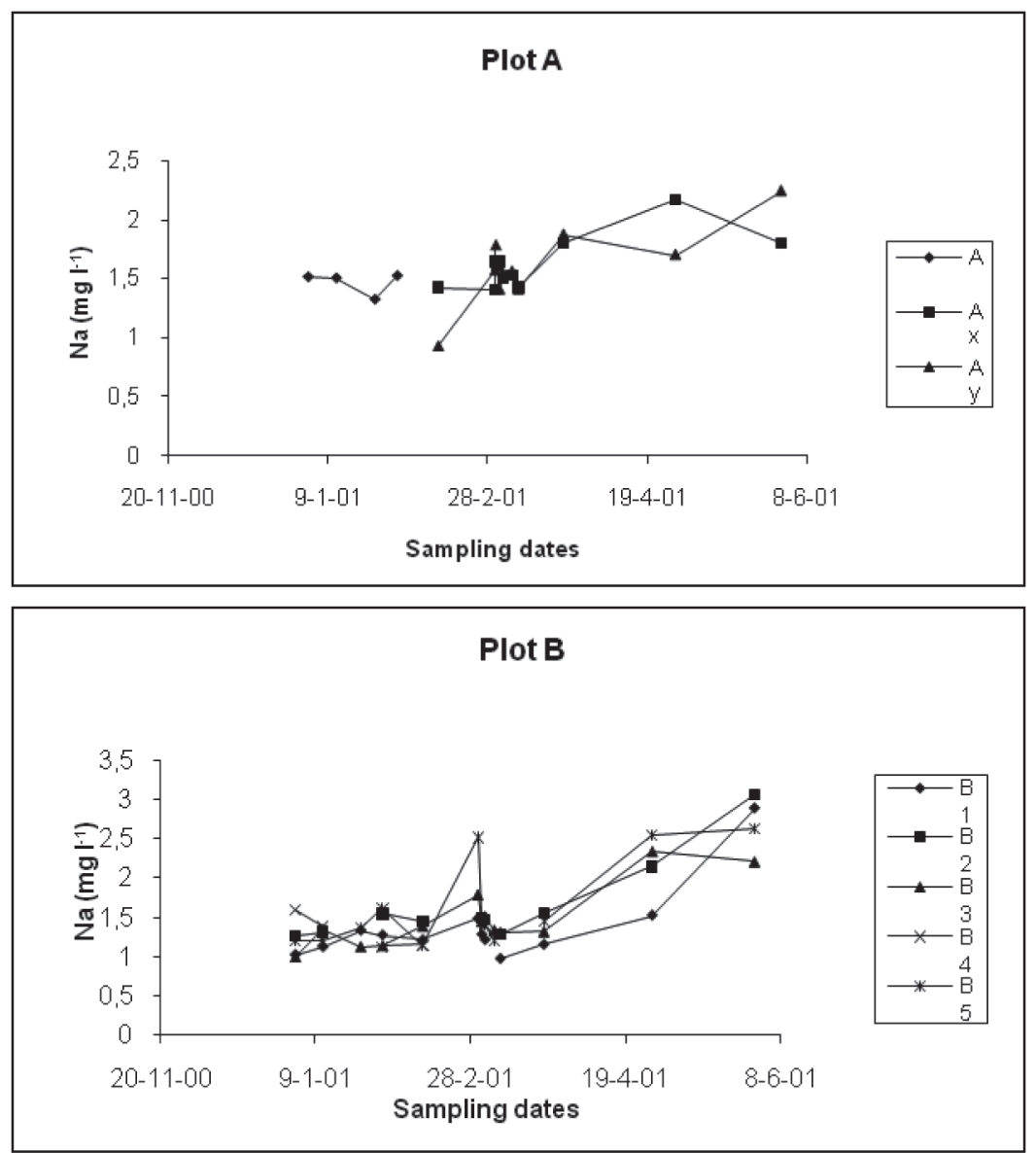

Figure 7. Time course evolution of $\mathrm{Na}\left(\mathrm{mg} \mathrm{l}^{-1}\right)$ in runoff samples collected in both plots. A: the whole plot A. Ax and Ay: sub-zones in plot A. B1 to B5: sub-zones in plot B

\section{Potassium}

Before ash spreading, $\mathrm{K}$ concentrations in plot A were about $1 \mathrm{mg} \mathrm{l}^{-1}$ (Figure 8). Rises of 0.47 and $0.38 \mathrm{mg} \mathrm{l}^{-1}$ were produced in the sub-zones Ax and Ay respectively at the first sampling date after ash spreading. The initial levels were recuperated at the third sampling date after the amendment, but a peak of potassium of $2.46 \mathrm{mg} \mathrm{l}^{-1}$ was detected latter in sub-zone Ax. Important rises, maintained until the end of the experience, were produced after April 9 and 23. At these moments, runoff water had $K$ concentrations of about $2 \mathrm{mg} \mathrm{l}^{-1}$, and finally reached values close to $3 \mathrm{mg} \mathrm{l}^{-1}$. 

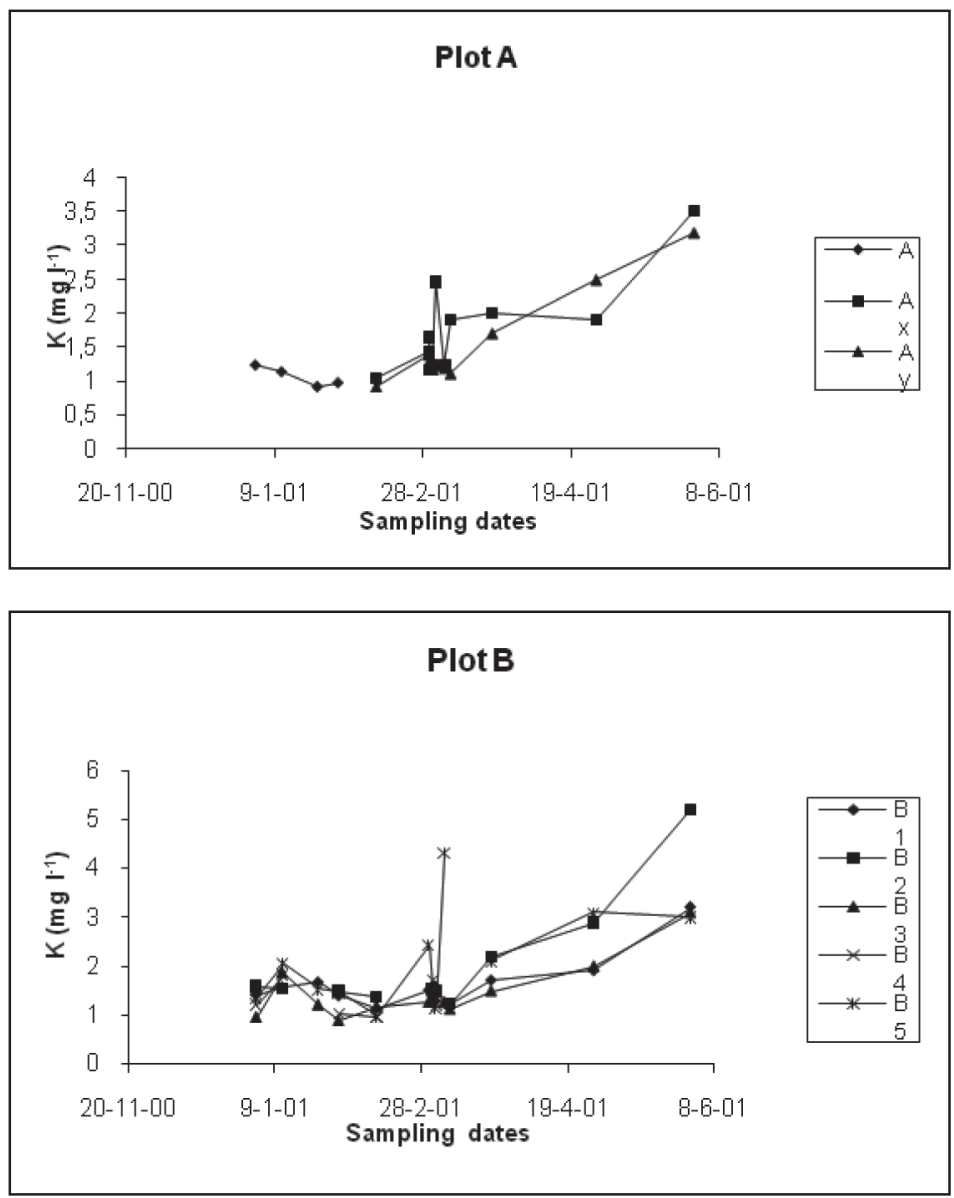

Figure 8. Time course evolution of $\mathrm{K}_{\left(\mathrm{mg} \mathrm{l}^{-1}\right)}$ in runoff samples collected in both plots. A: the whole plot A. Ax and Ay: sub-zones in plot A. B1 to B5: sub-zones in plot B

The dynamics in the samples of plot B are similar: initial stabilisation at about 1-1.5 $\mathrm{mg} \mathrm{l}^{-1}$ and not much appreciable rises after treatment, except in the sub-zone B5, passing from 0.98 to $2.43 \mathrm{mg} \mathrm{l}^{-1}$ (a peak of $4.31 \mathrm{mg} \mathrm{l}^{-1}$ in the sampling of March 7 is also produced in this same sub-zone). A general rise of potassium contents in the plot was observed after March 23.

A certain similarity between the evolution of potassium and that corresponding to the electrical conductivity was also observed in this case.

\section{Heavy metals}

Heavy metals did not show hazardous values in runoff samples in most of the occasions.

Values up to $6 \mathrm{mg} \mathrm{l}^{-1}$ were detected in the case of zinc, but only in punctual sampling dates. Concentrations were usually situated under the limit of detection in most of the cases.

Peaks of 4 and $8 \mathrm{mg}^{-1}$ were found for aluminium in plots A and B respectively in two punctual dates after ash spreading. Aluminium was detected in other samples after the amendment, although in lower concentrations. 
A punctual peak of $0.76 \mathrm{mg} \mathrm{l}^{-1}$ appeared for copper, but with values situated below $0.2 \mathrm{mg} \mathrm{l}^{-1}$ in any other case.

Determinations of nickel, iron, led, manganese, chromium and cadmium were also made in runoff samples, and detectable values were not found except in some sampling dates, when concentrations were situated within the limit of detection. However, these values were found both before and after wood ash spreading, so this fact cannot be attributed to the ash amendment.

\section{Effects on surface water quality}

Paying attention to the Spanish legislation related to potable water (R.D. 1138/1990), the analysed runoff waters could enter public streams or infiltrate and reach subterranean aquifers.

Further, it must be taken into account that the runoff water here analysed probably will be diluted in the case of reaching a stream or an aquifer. Therefore, the concentrations could decrease.

It must also be noted that the admitted contents for the different parameters in water for human consumption are very low. For this reason those parameters surpassing these levels were compared to the "Order of May the $11^{\text {th }}$ of 1998 of Ministry of Public Works and Urbanism on basic characteristics of quality that must be maintained in surface water streams when destined to potable water" (MOPU 1988), which is a lesser exigent norm.

The measured ranges for these parameters in the analysed runoff waters, before and after the spreading of $10 \mathrm{Mg} \mathrm{ha}^{-1}$ of wood ash, are specified in table 6 . The reference levels established by the Spanish legislation also appear in the table.

Table 6. Maximum values of some parameters measured in runoff, before and after ash spreading, and those prescribed by the Spanish legislation for potable water destined to public consumption (R. D. 1138/1990)

\begin{tabular}{|c|c|c|c|}
\hline Parameter & Without ash & With ash $\left(10 \mathrm{t} \mathrm{ha}^{-1}\right)$ & Legislation \\
\hline $\mathrm{pH}$ & 5.35 & 6.38 & $6.5-8.5$ \\
\hline $\mathrm{EC}\left(\mu \mathrm{S} \mathrm{cm}^{-1}, 20^{\circ} \mathrm{C}\right)$ & 65.1 & 54.7 & 400 \\
\hline Suspended solids $\left(\mathrm{mg} \mathrm{l}^{-1}\right)$ & 941.1 & 162.5 & 0 \\
\hline $\mathrm{Ca}\left(\mathrm{mg} \mathrm{l}^{-1}\right)$ & 1.47 & 12.31 & 100 \\
\hline $\operatorname{Mg}\left(\mathrm{mg} \mathrm{l}^{-1}\right)$ & 0.72 & 0.75 & 50 \\
\hline $\mathrm{Na}\left(\mathrm{mg} \mathrm{l}^{-1}\right)$ & 2.27 & 3.06 & 150 \\
\hline $\mathrm{K}\left(\mathrm{mg} \mathrm{l}^{-1}\right)$ & 3.44 & 5.15 & 12 \\
\hline $\mathrm{Al}\left(\mathrm{mg} \mathrm{l}^{-1}\right)$ & $<0.3$ & 7.93 & 0.2 \\
\hline $\mathrm{Fe}\left(\mathrm{mg} \mathrm{l}^{-1}\right)$ & 1.24 & $<0.5$ & 0.2 \\
\hline $\operatorname{Mn}\left(\mathrm{mg} \mathrm{l}^{-1}\right)$ & 0.31 & 0.64 & 0.05 \\
\hline $\mathrm{Cu}\left(\mathrm{mg} \mathrm{l}^{-1}\right)$ & $<0.2$ & 0.76 & 0.1 \\
\hline $\mathrm{Zn}\left(\mathrm{mg} \mathrm{l}^{-1}\right)$ & 2.76 & 5.87 & 0.1 \\
\hline $\mathrm{Pb}\left(\mathrm{mg} \mathrm{l}^{-1}\right)$ & $<0.5$ & $<0.5$ & 0.05 \\
\hline $\mathrm{Ni}\left(\mathrm{mg} \mathrm{l}^{-1}\right)$ & 1.3 & 0.9 & 0.05 \\
\hline
\end{tabular}

The $\mathrm{pH}$ values were in all samples below the recommended threshold limits for potable water, even after ash addition.

The electrical conductivity was always under the guide levels for potable water.

The presence of suspended solids can be mainly attributed to the circulation of runoff water through the vegetable remains covering the soil surface, even observing higher suspended solids levels in those episodes that generate smaller runoff volumes. 
Increases in the concentration of basic cations $(\mathrm{Ca}, \mathrm{Mg}, \mathrm{Na}$ and $\mathrm{K})$ in runoff water were observed after the ash spreading. Only the concentration of potassium reached a level as high as half of the concentration permitted by the legislation relative to potable water. The concentrations of the other three basic cations were clearly smaller.

It seems that the ash spreading is involved in the appearance of aluminium in runoff water, because it was not detected previously.

The concentration of $Z n$ surpassed in all samples the value marked by the legislation related to water destined to human consumption, but this was both before and after ash spreading. The Spanish limit for water susceptible of being subjected to intense and complete treatment for production of potable water (5 $\mathrm{mg} \mathrm{l}^{-1}$, MOPU 1988) is only surpassed in one sample after ash amendment.

Concentrations above those established by the Spanish legislation were found in some samples in the cases of iron, led and nickel, but in most of the cases the concentrations were lower.

\section{CONCLUSIONS}

After the spreading of a dose of $10 \mathrm{Mg} \mathrm{ha}^{-1}$ of wood ash on an acid forest soil, in two sloped experimental plots, we have not detected an important direct ash drag effect, even in episodes with high rainfall (clearly higher than the long term average in the zone) and runoff. The solubilisation by water is responsible of mobilisation for most elements and compounds.

There were not great differences on pollutant substances content in water and nutrient losses by runoff in the plots, before and after ash spreading. There were not serious environmental risks, even on high rainfall and runoff events, neither for excess of mobilisation of nutrients nor for soluble salts, COD or heavy metals in runoff waters.

We have not detected a significant relationship between concentrations of the analysed chemical parameters and the runoff volumes, but it seems to exist a progressive drag of substances that affect certain parameters (such as $\mathrm{pH}, \mathrm{EC}$, some of the basic cations and aluminium), as a function of accumulated runoff volumes and in different runoff episodes, from the upper zones of the plots and all along them. This fact provokes detectable rises in concentrations only after certain time passes from ash spreading.

More research is needed, but wood ash seems to be an amendment that could be useful for contributing to correcting soil $\mathrm{pH}$ and to increase soil fertility in acid sloped forest areas, there being with minor environmental risks to runoff water quality. 


\section{REFERENCES}

APHA, American Public Health Association. 1998. Standard methods for the examination of water and wastewater. APHA, Washington D.C.USA. 1268 pp.

Büttner, V.; Gering, C.; Nell, U.; Rumpf, S.; Wilpert, K.V. 1995. Einsatz von Holzasche in Wäldern (Wood ash application in forest). Forst und Holz 53: 72-76.

Campbell, A.G. 1990. Recycling and disposing of wood ash. Tappi Journal 73: 141-146.

Clapham, W.M.; Zibilske, L.M. 1992. Wood ash as a liming amendment. Communications in Soil Science and Plant Analysis 23: 1229-1227.

Demeyer, A.; Voundi, J.C.; Verloo, M.G. 2001. Characteristics of wood ash and influence on soil properties and nutrient uptake: an overview. Bioresource Technology 77 (3): 287-295.

Erich, M.S. 1991. Agronomic effectiveness of wood ash as a source of phosphorus and potassium. Journal of Environmental Quality 20: 576-581.

Erich, M.S.; Ohno, T. 1992. Phosphorus availability to corn from wood ash-amended soils. Water, Air and Soil Pollution 64: 475-485.

Etiégni, L.; Campbell, A.G. 1991. Physical and chemical characteristics of wood ash. Bioresource Technology 37: 173-178.

Etiégni, L.; Campbell, A.G.; Mahler, R. L. 1991. Evaluation of wood ash disposal on agricultural land. I. Potential as soil additive and liming agent. Communications in Soil Science and Plant Analysis 22: $243-256$.

Guitián, F.; Carballas, T. 1976. Técnicas de análisis de suelos. Ed. Pico Sacro, Santiago de Compostela. España. 288 pp.

Huang, H.; Campbell, A.G.; Folk, R.; Mahler, R.L. 1992.Wood ash as a soil additive and liming agent for wheat: field studies. Communications in Soil Science and Plant Analysis 23: 25-33.

Huotari, N.;Tillman-Sutela, E.; Kubin, E. 2011.Ground vegetation has a major role in element dynamics in an ash-fertilizedcut-away peatland. Forest Ecology and Management 261: 2081-2088.

Khal, J.S.; Fernández, I.J.; Lindsey, E.R.; Peckenham, J. 1996. Threshold application rates of wood ash to an acidic forest soil. Journal of Environmental Quality 25: 220-227.

Klute, A. 1986. Water retention: laboratory methods. In Methods of Soil Analysis. Part 1 (Edited by Klute A.).ASA and SSSA, Madison. USA. 1188 pp.

Moilanen, M.; Silfverberg, K.; Hokkanen, T.J. 2002. Effects of wood-ash on tree growth, vegetation and substrate quality of a drained mire: a case study. Forest Ecology and Management 171: 321-338.

Moilanen, M.; Fritze, H.; Nieminen, M.; Piirainen, S.; Issakainen, J.; Piispanen, J. 2006. Does wood ash application increase heavy metal accumulation in forest berries and mushrooms? Forest Ecology and Management 226: 153-260. 
MOPU, Ministerio de Obras Públicas y Urbanismo. 1988. Orden de 11 de mayo de 1988 del Ministerio de Obras Públicas y Urbanismo. Características básicas de calidad que deben ser mantenidas en las corrientes de agua superficiales cuando sean destinadas a la producción de agua potable. BOE, Madrid. España: 15823-15824.

Muse, J.K.; Mitchell, C.C. 1995. Paper mill boiler ash and lime by-products as soil liming materials. Agronomy Journal 87: 432-438.

Naylor, L.M.; Schmidt, L. 1986. Agricultural use of wood ash as a fertilizer and liming material. Tappi Journal 69: 114-119.

Núñez, A.; López, E.; Quiroga, F.; Díaz-Fierros, F. 2001. Surface runoff pollution by cattle slurry and inorganic fertilizer spreading: COD, O-P and E.C. levels for different buffer strip lengths. Water Science Technology 44(1):173-180.

Ohno, T. 1992. Neutralization of soil acidity and release of phosphorus and potassium by wood ash. Journal of Environmental Quality 21: 433-438.

Ohno, T.; Erich, M.S. 1990. Effect of wood ash application on soil pH and soil test nutrient levels. Agriculture, Ecosystems and Environment 32: 223-239.

Page, A.L.; Miller, R.; Keeney, D.T. 1982. Methods of soil analysis. Part 2. Chemical and Microbiological properties. American Society of Agronomy, Inc. Soil Sci. Soc. Am., Inc Publisher, Madison. 1159 pp.

Quiroga, F.; Núñez, A.; Soto, B. 2002. Performance of forest plots in runoff water research. A case study. In: Res. Adv. in Water Research 3 (Mohan, R.M., Ed.). Global Research Network, Kerala. 1-5.

Piirainen, S. 2001. Ash fertilization and leaching of nutrients from drained peatland. Environmental consequences of recycling wood-ash to forest. The Forestry Research Institute of Sweden. Report $\mathrm{N}^{\circ}$ 2, Stockholm. Sweden. 21-24.

REAL DECRETO 1138. 1990. Reglamentación Técnico-Sanitaria para el abastecimiento y control de Calidad de las Aguas Potables de Consumo Público. RD 1138/1990. 14 de septiembre 1990. BOE, Madrid. España. 27488- 27497.

Silverberg, K.; Hotanen, J.P. 1989. Long-term effects of wood ash on a drained mesotrophic Sphagnum papillosum in Oulu district. Finland. Folia For. 742: 1-23.

Someshwar, A.V. 1996. Wood and combination wood-fired boiler ash characterization. Journal of Environmental Quality 25: 962-972.

Soto, B.; Díaz-Fierros, F. 1993. Interactions between plant ash leachates and soil. Int. J. Wildland Fire 3 (4): 207-216.

Sueiro, P. 2010. Inertización y promoción del reciclado de restos pastosos de fuel mediante mezclado con encalantes, cenizas y lodos. Ph. D. Thesis, Univ. Santiago de Compostela. Depto. Edafología y Química Agrícola. Escuela Politécnica Superior. Santiago de Compostela, España. 876 pp.

Tan, K.H. 1996. Soil sampling, preparation and analysis. Marcel Dekker, Inc., New York. USA. $408 \mathrm{pp}$. 
Ulery, A.L.; Graham, R.C.; Amrhein, C. 1993. Wood ash composition and soil pH following intense burning. Soil Science 156: 358-364.

USEPA, U.S. Environmental Protection Agency. 1993. Title 40 CFR. Part 503. Standards for use and disposal of sewage of sludge. Subpart B. Land application. Section 503. 13. Pollutant limits. Washington. USA. 3 pp.

Vance, E.D. 1996. Land application of wood fired and combination boiler ashes: An overview. Journal of Environmental Quality 25: 937-944.

Voundi, J.C.; Nkana, A.; Demeyer, A.; Verloo, M.G. 2000. Nutrient dynamics in tropical acid soils amended with wood ash. Agrochimica XLIV(5-6): 197-210.

WHO, World Wealth Organization. 1998. Guías para la calidad del agua potable. Vigilancia y control de los abastecimientos de agua a la comunidad. Biblioteca de la OMS, Ginebra.

Williams, T.M.; Hollis, C.A.; Smith, B.R. 1996. Forest soil and water chemistry following bark boiler bottom ash application. Journal of Environmental Quality 25: 955-961.

Zollner, V.A.; Remler, N. 1998. Eigenschaften von Holzaschen und Möglichkeiten de Wiederverwertung. (Properties of wood ash and possibilities of recycling). Fort und Holz 53: 77-81. 